\title{
Sexual transmission of Zika virus in an entirely asymptomatic couple returning from a Zika epidemic area, France, April 2016
}

T Fréour ${ }^{12}$, S Mirallié ${ }^{12}$, B Hubert ${ }^{3}$, C Splingart ${ }^{1}$, P Barrière ${ }^{1}$, M Maquart 4 , I Leparc-Goffart 4

1. Service de médecine de la reproduction, CHU de Nantes

2. These authors contributed equally as first authors

3. Santé publique France, French national public health agency, Regional unit (Cire) Pays de la Loire, Saint-Maurice, France

4. French Armed Forces Biomedical Research Institute, Marseille, France

Correspondence: Isabelle Leparc-Goffart (isabelle.leparcgoffart@gmail.com)

Citation style for this article:

Fréour T, Mirallié S, Hubert B, Splingart C, Barrière P, Maquart M, Leparc-Goffart I. Sexual transmission of Zika virus in an entirely asymptomatic couple returning from a Zika epidemic area, France, April 2016. Euro Surveill. 2016;21(23):pii=30254. DOI: http://dx.doi.org/10.2807/1560-7917.ES.2016.21.23.30254

The current Zika virus outbreak and its potential severe health consequences, especially congenital fetal syndrome, have led to increased concern about sexual transmission, especially in pregnant women and women of reproductive age. Here we report a case of Zika virus sexual transmission, likely male-tofemale, in a totally asymptomatic couple.

Zika virus (ZIKV) is a mosquito-borne flavivirus transmitted by Aedes species $[1,2]$. It is also the first flavivirus known to be sexually transmittable between symptomatic patients [3-6]. We here report a ZIKV sexual transmission in a couple returning from Martinique, whereby both partners were asymptomatic.

\section{Description of cases}

A couple wishing to have children was referred to our Assisted Reproduction Treatment (ART) centre for in vitro fertilisation with donor semen (IVF-D), as the male partner had non-obstructive azoospermia. The couple presented for a first consultation in early February 2016 in preparation of an IVF-D cycle scheduled two months later. Until this time, they had planned to spend a twoweek holiday in early March in the French overseas department and region of Martinique, which is an epidemic area for ZIKV [7].

On the day before the first consultation, guidelines issued by the French governmental agency regulating ART, had been released concerning ZIKV. In the case of the couple, these guidelines recommended that both partners be tested for ZIKV RNA by reverse transcription-polymerase chain reaction (RT-PCR) in blood and urine samples at least 28 days after they came back from Martinique [8]. In addition, at the same occasion and according to the guidelines, samples of the man's seminal plasma and sperm cell suspension obtained after sperm preparation on gradient were also to be tested for ZIKV RNA by RT-PCR [8]. The couple was thus informed that the IVF-D cycle would be delayed and an appointment for the ZIKV RNA tests was scheduled 39 days after their return from the holiday (Figure).

Virological diagnosis was performed as previously described [3]. The woman tested positive for ZIKV RNA by RT-PCR in blood (i.e. serum) and urine samples. The man tested negative for ZIKV RNA in blood, but positive in urine and seminal plasma. Sperm cell suspension was not tested for ZIKV, as he was azoospermic. Serological analysis for the man indicated the presence of anti-ZIKV IgM (absence of anti-dengue IGM) and antiflaviviruses IgG. At the time of the consultation and during the following week, both partners reported having no clinical symptoms of ZIKV infection during and after their stay in Martinique (i.e. no fever, cutaneous manifestation, arthritis, nor myalgia).

As Ae. albopictus and Ae. aegypti are not established in Brittany where the patients lived, the hypothesis of a local vector-borne infection was excluded. Due to the absence of clinical symptoms, the probable date of exposure to ZIKV could not be determined from the incubation period range. Instead, we used data from a systematic review of the time of viral clearance estimating that $5 \%$ of cases will have no detectable virus in the blood by 2.4 days after infection and $95 \%$ by 18.9 days [9]. The results of the blood tests, whereby the man tested negative for the virus, while the woman tested positive, pointed to him having been infected before her. The most likely period of exposure to ZIKV for the man was during his stay in Martinique. The woman was found to be viraemic in blood 39 days after her return, which if she had been infected at any time during the holiday trip would correspond to at least 20 
Timelines showing the key dates of possible exposure to Zika virus (ZIKV) for two cases of ZIKV infection and results of ZIKV reverse transcription-polymerase chain reaction tests on blood, urine or semen, France, March-April 2016

Woman

days longer than the maximal time of viral clearance (Figure). These data, associated with the detection of ZIKV RNA in the man's semen, support the hypothesis of ZIKV sexual transmission from the man to the woman between day 21 and day 36 after their return from Martinique. The couple reported having several unprotected sexual intercourses after their return.

\section{Background}

ZIKV is an emerging flavivirus currently responsible for a major outbreak in different areas of the world including for example South America, as well as islands of the Caribbean and the Pacific [7]. In addition to the vector-borne transmission of the virus by $A e$. aegypti or Ae. albopictus, evidence of sexual transmission has been reported between symptomatic patients, from men-to-women or from men-to-men [3-6]. The interval between the onset of symptoms in the man and his partner has been observed to vary from 4 to 44 days [10]. Recently published data show a higher incidence of ZIKV infection in women of reproductive age in Brazil, suggesting a potential role for sexual transmission in the outbreak dynamic [11]. Knowledge on the maximum delay for possible sexual transmission from the time of infection, as well as knowledge of possible transmissions from asymptomatic infected individuals, are of real interest for public health in terms of establishing control measures, improving surveillance to detect the emergence of ZIKV in areas with no current circulation but where Aedes is established, and in terms of understanding the outbreak dynamic.

\section{Discussion and conclusions}

The finding in our study of a likely man-to-woman sexual transmission of ZIKV between two asymptomatic cases coincided with systematic virological testing in the context of ART. To date, all reported sexual transmissions implicated an index case with symptoms of
ZIKV infection, either during a stay in an epidemic area or during the 2 weeks after return from such an area $[3-6,10]$.

As up to $80 \%$ of patients infected with ZIKV remain asymptomatic, the level of sexual transmission could play a more important role than expected in the overall dynamic of ZIKV circulation [12]. This unapparent risk of transmission is of concern for pregnant women and women considering pregnancy, and highlights the need to reinforce the counselling and recommendations given to men travelling to epidemic regions and having sex with women of reproductive age. The possible sexual transmission from asymptomatic cases also increases the risk of emergence of ZIKV in Europe in areas where Ae. albopictus and Ae. aegypti are present.

ZIKV sexual transmission has been reported to occur up to 41 days after the onset of symptoms of the index case and ZIVK RNA has been detected in semen samples at 62 days post-symptom onset $[10,13]$. Issues related to viral presence and load in semen have been recently highlighted for Rift Valley fever virus and Ebola virus $[14,15]$, whereby questions on the potential consequences have been raised for Ebola virus, as its long-lasting persistence has been shown in semen of survivors [15]. Whether the seminal level of ZIKV RNA follows the same slow decreasing pattern than Ebola virus is not known, but can be expected.

Crucial questions remain to be addressed regarding ZIKV sexual transmission. First, the prevalence of ZIKV persistence in semen needs to be clarified in large epidemiological studies. Second, describing the duration of virus persistence in semen and the dynamics of RNA viral load in semen will help decipher the virus pathophysiological cycle in the male genitourinary tract. These data are of utmost importance in order 
to determine the overall probability of ZIKV sexual transmission.

\section{Conflict of interest}

None declared.

\section{Authors' contributions}

Wrote the manuscript: TF, SM; performed laboratory investigations: MM, IL-G; managed the patients and lead the epidemiological investigation: $\mathrm{BH}, \mathrm{TF}, \mathrm{SM}, \mathrm{CS}, \mathrm{PB}$; revised the manuscript: $\mathrm{BH}, \mathrm{IL}-\mathrm{G}$

\section{References}

1. Marchette NJ, Garcia R, Rudnick A. Isolation of Zika virus from Aedes aegypti mosquitoes in Malaysia.Am J Trop Med Hyg. 1969;18(3):411-5.PMID: 4976739

2. Grard G, Caron M, Mombo IM, Nkoghe D, Mboui Ondo S, Jiolle D, et al. Zika virus in Gabon (Central Africa)--2007: a new threat from Aedes albopictus? PLoS Negl Trop Dis. 2014;8(2):e2681. DOI: 10.1371/journal.pntd.0002681 PMID: 24516683

3. D’Ortenzio E, Matheron S, Yazdanpanah Y, de Lamballerie X, Hubert B, Piorkowski G, et al. Evidence of Sexual Transmission of Zika Virus. N Engl J Med. 2016;374(22):2195-8. DOI: 10.1056/NEJMc1604449 PMID: 27074370

4. Hills SL, Russell K, Hennessey M, Williams C, Oster AM, Fischer M, et al. Transmission of Zika Virus Through Sexual Contact with Travelers to Areas of Ongoing Transmission Continental United States, 2016. MMWR Morb Mortal Wkly Rep. 2016;65(8):215-6. DOI: 10.15585/mmwr.mm6508e2 PMID: 26937739

5. Deckard DT, Chung WM, Brooks JT, Smith JC, Woldai S, Hennessey M, et al. Male-to-Male Sexual Transmission of Zika Virus - Texas, January 2016. MMWR Morb Mortal Wkly Rep. 2016;65(14):372-4. DOI: 10.15585/mmwr.mm6514a3 PMID: 27078057

6. Venturi G, Zammarchi L, Fortuna C, Remoli ME, Benedetti E, Fiorentini C, et al. An autochthonous case of Zika due to possible sexual transmission, Florence, Italy, 2014. Euro Surveill. 2016;21(8):30148. DOI: 10.2807/1560-7917. ES.2016.21.8.30148 PMID: 26939607

7. European Centre for Disease Prevention and Control (ECDC). Current Zika transmission. Last updated 8 Jun 2016. Stockholm: ECDC. [Accessed og Jun 2016]. Available from: http://ecdc.europa.eu/en/healthtopics/zika_virus_infection/ zika-outbreak/Pages/Zika-countries-with-transmission.aspx

8. Agence de la Biomédecine. Recommandations professionnelles dans le cadre de l'épidémie de virus Zika. French. Available from: http://www.agence-biomedecine.fr/IMG/pdf/2016-003_ reco_amp_et_zika_18-03-2016_.pdf

9. Lessler JT, Ott CT, Carcelen AC, Konikoff JM, Williamson J, Bi Q, et al. Times to key events in the course of Zika infection and their implications: a systematic review and pooled analysis [Submitted]. Bull World Health Organ. 2016;1. DOI: 10.2471/ BLT.16.174540

10. Turmel JM, Abgueguen P, Hubert B, Vandamme YM, Maquart $M$, Le Guillou Guillemette $\mathrm{H}$, et al. Late sexual transmission of Zika virus related to probable long persistence in the semen. Lancet. 2016.

11. Coelho FC, Durovni B, Saraceni V, Lemos C, Codeço CT, Camargo $\mathrm{S}$, et al. Sexual transmission causes a marked increase in the incidence of Zika in women in Rio de Janeiro, Brazil. Available from: http://biorxiv.org/content/ early/2016/05/26/055459

12. Duffy MR, Chen TH, Hancock WT, Powers AM, Kool JL, Lanciotti RS, et al. Zika virus outbreak on Yap Island, Federated States of Micronesia. N Engl J Med. 2009;360(24):2536-43. DOI: 10.1056/NEJMoa0805715 PMID: 19516034

13. Atkinson B, Hearn P, Afrough B, Lumley S, Carter D, Aarons EJ, et al. Detection of Zika Virus in Semen. Emerg Infect Dis. 2016;22(5):940. DOI: 10.3201/eid2205.160107 PMID: 27088817

14. Haneche F, Leparc-Goffart I, Simon F, Hentzien M, MartinezPourcher V, Caumes E, et al. Rift Valley fever in kidney transplant recipient returning from Mali with viral RNA detected in semen up to four months from symptom onset,
France, autumn 2015. Euro Surveill. 2016;21(18):30222. DOI: 10.2807/1560-7917.ES.2016.21.18.30222 PMID: 27172608

15. Sow MS, Etard JF, Baize S, Magassouba N, Faye O, Msellati P, et al. , Postebogui Study Group. New Evidence of Longlasting Persistence of Ebola Virus Genetic Material in Semen of Survivors.J Infect Dis. 2016:jiw078. DOI: 10.1093/infdis/jiw078 PMID: 27142204

\section{License and copyright}

This is an open-access article distributed under the terms of the Creative Commons Attribution (CC BY 4.0) Licence. You may share and adapt the material, but must give appropriate credit to the source, provide a link to the licence, and indicate if changes were made.

This article is copyright of the authors, 2016. 